\title{
Never the Twain Shall Meet: A critical appraisal of the combination of discourse and psychoanalytic theory in studies of men and masculinity
}

\begin{abstract}
In recent years there has been a number of attempts by different researchers to study men and masculinity using a combination of discourse theory and psychoanalysis. The main reason for this development is the sense that, on its own, discourse theory provides an incomplete account of masculine subjectivity. Psychoanalysis is thought to be able to fill those gaps. In this paper I want to begin by reviewing these arguments. I will provide an outline of the alleged deficiencies in discursive approaches to men and masculinity before going on to examine some of the work that has attempted the above synthesis. What I aim to show is that, for a number of reasons, such attempts are bound to fail. Instead, I will argue that better progress can be made in studies of masculinity by remaining within the theoretical boundaries of Discursive Psychology.
\end{abstract}

KEYWORDS: Discursive Psychology, psychoanalysis, masculinity, homophobia, ego-defence, subject positions, rhetoric.

\section{Introduction}

In recent years there has been a steady accumulation of work that has taken a discursive approach to studying men and masculinity (e.g. Berger et al., 1995; Edley, 2001; Edley \& Wetherell, 1997, 1999; Frosh, 2000; Frosh et al, 
2002; Gough, 1998, 2004; Johnson and Meinhof, 1997; Redman, 2000;

Wetherell \& Edley, 1999; Willott \& Griffin, 1997). Central to this body of work is the claim that masculinity is not something that stands outside of discourse as an essential aspect or quality of men; instead, it is seen as something that is routinely constructed in and through discourse. Following the pioneering work of Harold Garfinkel (1967), Susan Kessler and Wendy McKenna (1978) and Candice West and Don Zimmerman (1987), these studies have looked at the discursive accomplishment of masculinity. More specifically, they have analysed both how the meaning of masculinity is sustained and renegotiated in discourse and also how masculine identities are flexibly constructed and deployed in a variety of different contexts or settings.

Despite the significant achievements of these studies there has also been, at the same time, a clear concern expressed across the human and social sciences about the overall adequacy of such discourse-based approaches. Broadly understood, these concerns tend to focus upon two central issues. The first consists of the claim that most discourse approaches lack an appropriate ontology of the self. In other words, it is felt that such studies contribute little, if anything, to an understanding of what might be somewhat 
euphemistically described as the mind behind the mouth. Taking Discursive Psychology (henceforth DP) as a case in point, one can easily see the grounds for such a complaint, for within that approach, questions regarding the nature of the speaking subject are typically suspended or 'bracketed out' (see Edwards and Potter, 1992; c.f. Berger and Luckmann, 1985).

Discursive Psychologists, like many other discourse theorists, typically adopt an agnostic position with respect to issues of ontology. What they analyse instead are the ways that debates about, for example, 'the nature of men' are played out in ordinary everyday discourse. In other words, the 'reality' of men or masculinity is treated, within DP, as both a topic and an outcome of 'participants'” discourse practices.

Nevertheless, if one thinks about the model of the human subject implied, at least, by DP it is hard to deny that it appears somewhat deflated or truncated. Some of the things that have been traditionally understood as laying at the very heart of people - like attitudes, memories and emotions - have been reinterpreted within DP as ‘structures of social action' (Atkinson \& Heritage, 1984); that is, as forms of discourse produced inter-actively in various contexts or settings. Indeed, in the work of some Discursive Psychologists (e.g. Antaki and Widdicombe, 1998), identity itself is treated 
as a discursive resource - rather than as the origin point of language.

Likewise, for many post-structuralist theorists (e.g. Laclau \& Mouffe, 1985), identities are understood as discursive effects. They are said to represent 'nodes' within discourse; points or moments of articulation that temporarily position people as particular kinds of beings in the world. All this has led some critics to complain that discourse theory has gone too far in its 'decentring' of the Cartesian subject. Indeed, in the opinion of some, it has all but been pushed off the theoretical map.

[In DP] self is studied only in terms of individual, discursive acts which perform various social activities such as presenting a certain image of the self, excusing, blaming, and so on. This results in a conception of self in which subjective experience [...] is made so context dependent, so fluid and flexible, that there seems to be little beyond a personal psychology which is a moment-to-moment situated experience. Language and context are emphasized to such an extent that the self is engulfed, if not annihilated (Crossley, 2000, pg. 530).

For critics such as Crossley, the model of the human subject afforded by approaches such as DP stands at simply too great a distance from its phenomenological or experiential reality. Their point is that, despite the claims of discourse theory, in our everyday lives, people do actually feel themselves to be something more substantial and enduring. As Mark Freeman (1993) wryly observes: 
Even if we deconstruct the subject to pieces and argue over the duplicity of the self and the multiplicity of the self and the fictionality of the self and a thousand other things that the self isn't besides whole, centred, integrated, unified and what have you - don't most of us continue to posit in a rather unabashedly romantic fashion that there are some things that are really 'us' and other things that are not? (pg. 207).

For Freeman, any adequate theory of identity has 'to do justice to the lives we live' (1993; 13). It has to be able to account for that sense of depth, particularity and continuity across both space and time. It also has to account, he suggests, for what one might call the stickiness of identity - a point that brings us on to the second key concern about discourse-based approaches.

Amongst discourse theories, DP has been particularly concerned to challenge essentialist understandings of identity. In our masculinities research, for example, Margie Wetherell and I have drawn repeated attention to the flexibility with which men construct their own, and others', identities (Edley and Wetherell, 1997; 1999; Wetherell and Edley, 1999). Here, 'who' or 'what' men are appears to be fluid and indeterminate, rather than permanent or fixed. However, this kind of work has led some critics to argue that discourse theory peddles an implicit model of the human subject 
in which speakers seem to be able to make entirely strategic or 'executive' decisions about which identity to adopt in any given context (see Bowers, 1988 and Parker, 1997). For them such a view greatly exaggerates the extent of human agency ${ }^{1}$. As far as Freeman (1993) is concerned, people are all too aware of the limits of identity. The existence of so many therapists, counsellors and self-help books would seem to testify, he would argue, not just to the fact that many people feel unhappy with (at least aspects of) themselves, but also to the fact that it is no simple matter to change. In life, Freeman says, people feel bound to certain ways of being and yet, the critics claim, discourse theory offers little or no insight into the nature of those bonds.

Given that discourse theory is seen to lack (i) an appropriate ontology of the self and (ii) an adequate account of the 'fixations' of identity, it is little wonder that a number of researchers interested in studying men and masculinity have turned their attentions to psychoanalysis; for across the social sciences it remains unparalleled as an account (or series of accounts) of the 'interior' workings of the human mind. Psychoanalysis provides us with a detailed model of both the structure and the processes of the psyche 
which, according to the likes of Frosh (1999), help us to explain, not just how identities are discursively constructed, but also why.

\section{Surveying the Synthesis}

In order to illustrate how discourse theory and psychoanalysis have been brought together in the study of men and masculinity, I will be drawing upon three bodies of work: Tony Jefferson’s studies of Mike Tyson (Jefferson, 1996; 1997; 1998), Stephen Frosh and colleagues’ work on 'young' masculinities (2000, 2002, 2003) and Brendan Gough’s (2004) research on, predominantly, male undergraduates. In all of these instances the authors concerned align themselves explicitly with most of the central tenets of discourse theory. All accept, for example, that people see the world through discourse and that language mediates one's experiences of the world. All appear to accept too that discourse makes available various locations or ‘subject positions’ (Davies and Harré, 1990) for people to occupy. However, what particularly unites this group is the belief that discourse theory cannot adequately account for the ‘choices’ that men make with respect to those discursive possibilities (see, for example, Frosh et al, 2003). 
To do that, they argue, one needs a psychic as well as a social level of explanation.

Although some are more forthcoming than others about the precise details of their own theoretical foundations, all of the above authors place a particular emphasis upon the notion of anxiety and its everyday management or control. In his collaboration with Wendy Hollway, for example (Hollway and Jefferson, 2000), Jefferson draws upon the work of Melanie Klein (Klein, 1988a and b). Following Klein, he suggest that anxiety is intrinsic to all human existence, stemming from our earliest experiences of absolute dependency - when the infant has no sense of when or even if it is going to be looked after and fed. As a result, Klein argued, from a very tender age people come to employ various ego-defence mechanisms - such as splitting, projection and repression - which are all designed to protect a person's ego and to shore-up their sense of self-worth.

In the latter part of the 1990s Jefferson explored these ideas in a series of papers about the former world heavy-weight champion boxer, Mike Tyson (Jefferson, 1996; 1997; 1998). For Jefferson, Tyson represents a man who is firmly identified with what many of us working within the field would call 
hegemonic masculinity (Carrigan, Connell and Lee, 1985; see also Wetherell and Edley, 1999). In other words, he was (is) someone who saw himself as a hard man: tough, uncompromising and fiercely competitive. Of course, central to the concept of hegemonic masculinity is the notion that this is a celebrated or, in some way, privileged form of masculine identity - and, indeed, Tyson could well stand as a paradigmatic example of how, as an instantiation of that identity, he was able to court both enormous fame and fortune. Yet, for Jefferson, it is a mistake to see Tyson as a simple player or performer of macho masculinity. Rather, he suggests that there is something compulsive about this identity for Tyson. The boxer is presented as someone bound to a subject position that both makes and, subsequently, breaks him².

Jefferson substantiates this argument - in the time-honoured fashion of psychoanalysis - by tracing a line back through Tyson’s early development. There he notes how, as a child, Tyson was constantly teased and bullied by his peers. Indeed, almost unbelievably, his nickname at one time was 'little fairy boy' - in respect of the fact that he was seen as both socially retiring and spoke with a conspicuous lisp. The story goes however that one day, in a transforming moment, the young Tyson effectively struck back at his tormentors. From that point onwards, it is claimed, Tyson became the 
prosecutor, rather than the victim, of oppressive behaviour. Jefferson notes that in his life as an up-and-coming boxer (following a visit to his neighbourhood by Mohammed Ali), one thing that apparently stood out about Tyson was his 'burning intensity’. Echoing the more recent stories about the English rugby union star, Jonny Wilkinson, Tyson was said to practice long after all his contemporaries had packed up and gone home. For Jefferson, fighting appeared to have provided Tyson with the means of defending, not just his physical self, but also his fragile ego. It became his way of proving himself, both to himself, as well as to the world at large.

To some degree, of course, it could be argued that Tyson's case history represents just a more extreme example of a much more general set of psychodynamic processes found within every man and boy. As a number of different theorists have suggested (e.g. Chodorow, 1989; Frosh, 1993; Greenson, 1968; Seidler, 1989), there appears to be something inherently defensive about the nature of masculinity. 'Proving' one’s manhood seems to involve a continual 'flight' from the feminine. In psychoanalytic terms, it involves the active repudiation of an original identification (with the mother) which, for most men, is never completely broken. As such, it acts as a font of conflict, ambiguity and anxiety. From a psychoanalytic point of view, 
this would go some way to explaining the well documented fact that, in Britain at least, school playgrounds and classrooms are rife with homophobic discourse (where words like 'poof' and 'queer' are routinely used as insults or 'put-downs' - see Frosh, Phoenix and Pattman, 2002) for, according to its theories, such behaviour represents a fairly typical outcome of 'dangerous' thoughts and desires being split off from oneself and projected onto others ${ }^{3}$.

Due to the remoteness of his principal subject, Jefferson inevitably relies, in these studies, upon evidence gleaned from secondary texts about Mike Tyson (e.g. from published biographies). Very little, in terms of his data, comes straight from the boxer's mouth. By contrast, in both Stephen Frosh and Brendan Gough's research, the analysis of 'defensive' masculinities takes place using the transcripts of semi-structured interviews which are, in part at least, reproduced for the readers' benefit. As such, it is here that we can gain the clearest sense of how the melding of discursive and psychoanalytic approaches is managed empirically.

As at least partial advocates of discourse theory, these two authors subject their data to a form of rhetorical analysis, whereby the texts are monitored 
for their various 'action-orientations'. However, at the same time, both insist that there is a remainder; that this level of analysis does not exhaust all that patterns the text. Their participants' talk is also marked, they claim, by the traces of ego-defences. Gough (2004), for instance, talks of being drawn to moments in a transcript where speakers appear either say too much or too little. Reference is made to instances of 'unsolicited' themes (pg. 256) and to utterances that seemed unduly 'colourful' (pg. 254) or impassioned. Like recent talk about suicide bombers, single mothers or asylum seekers, there appears to be something else going on underneath the level of local pragmatics. Consider, for example, the following data extract (reproduced in full from Gough, 2004):

\section{Extract One}

Joe I know (.) like (.) a few gay lads that work at the club and when they see me they come up to me and give me a kiss on the cheek=

Trev $=$ oh no! (.) uhhh I just couldn't (.) its just not=

Joe =I call you love and flower but you dont get offended do you

Trev yeah (.) I mean (.)

Joe but what if I turned around and said I was gay (.) would you instantly dislike me because of it

Trev no (.) I mean I've got (.) I have got one gay friend and (...) I'm not bothered (.) as long as they don't come on to me

Joe so what makes you think that any homosexual's gonna come on to you

Trev well (.) I'm not bothered if they come on to me (.) as long as they don't! \{both laugh\} no (.)

Joe is it that it would repulse you to give a guy a kiss

Trev oh yeah (.) big time (.) yeah=

Joe =but why 
Trev it's just disgustin (.) I can't stand it (.) I just don't think its right

Joe what about a couple of girls snoggin?

Trev no it's not $=$

Joe $=$ if they were attractive

Trev if they were attractive (.) if they were attractive it \{both laugh\} no (.) it has a sexual tone yeah (.) but=

Joe =what if it was two attractive blokes

Trev there's no such thing (.) is there

Joe two of the guys from Levi ads with six packs and (.) all muscly and that

Trev I just don't understand it I don't know (.) I can't help it (.) not that I'm (bothered) anyway (.) I just can't stand it (.) it's just not on

In his analysis of this extract, Gough remarks on how 'Trev's' presentation of himself as liberal and rational is ruptured by moments of 'uncensored' 'horror and disgust' (pg. 256). Trevor might say that he’s 'not bothered' by homosexuality but it is clear, Gough argues, that he is. For Gough, the extract neatly documents Trevor's struggle - and ultimate failure - to contain deep-seated anxieties about his own gender and sexual identity. A similar kind of conclusion is drawn by Frosh, Phoenix and Pattman (2002) in their studies of 'young masculinities'. For example, in the following stretch of talk, a group of year 8 schoolboys are talking about the idea of appreciating other boys' good looks. 


\section{Extract Two}

Geoff 'Cos if a boy goes, 'You look really good looking' you gonna kinda run off but like

Sam Yeah, I'd knock 'em, I'd give 'em one

Arnie What are you some kind of a sicko or something [several laughing]

Dan There's no way you telling me I'm good looking

Geoff Yeah, he probably goes 'you're very nice looking'. [several laughing]

Sam You gay or something boy?

Once again we see the same kind of sentiments expressed. Like Trevor in Extract One, the boys seem to find it difficult to imagine finding another male attractive. Many, the authors claim, found the very idea pretty strange. Most were said to be uncomfortable even contemplating it. Here, as elsewhere in their data, the boys talk about homosexuality within the tropes of fear and loathing. The gay man is portrayed as both dangerous and despicable. What this illustrates, the authors conclude, is the 'ubiquity and intensity of fears about being thought of as gay' (pg. 189). These themes do not emerge because, in some way, they fit the demands of that particular rhetorical setting. Rather, it is claimed, they appear in discourse both as a reflection and as a working-through of tensions that mark the psyche of most men and boys. 


\section{Scrutinizing the Synthesis}

As is clear from the title of this paper, the broader aim of reviewing the attempted synthesis of discourse theory and psychoanalysis is not to arrive at its recommendation. Indeed, quite the reverse, it is to argue for its impossibility. However, it is important to make clear at this point that, in a sense, my objections are not to do with psychoanalysis (nor indeed discourse theory) per se - rather, they concern the viability of combining the two approaches.

At the heart of those misgivings is the point that, whilst the two paradigms share an obvious interest in analysing language, they theorise discourse in profoundly different ways. As is now well recognised, discourse analysts take language as their central topic or focus of interest. In other words, they look at language directly, in order to work out its functions or action orientations. In contrast, psychoanalysts take a much more traditional line or position. They are not so much interested in language per se, but in what it can tell us about the speaker's underlying state of mind. What this means, of course, is that, to some extent at least, psychoanalysis is predicated on the very model of language that discourse theory has served to destabilize. 
If we look at Gough’s (2004) analysis, for instance, we can see that he frequently treats language as if it was a transparent or 'do-nothing domain' (Edwards, 1997). When Trev says he’s 'disgusted’ by the thought of kissing another man, Gough treats this as simple statement of fact. When Trev says he 'can’t stand' homosexuals, again Gough takes this claim at face value. Of course, when Trevor claims he’s 'not bothered’ by homosexuality, Gough asserts that, in reality, he is bothered - but this act of interpretation is still located within the same model of language in which discourse maps (either well or ill) on to some other realm or domain.

Gough's analysis also treads on the toes of discourse theory insofar as it implies that the analyst is in a (privileged) position to arbitrate over the nature of the Real. Clearly, in order to gloss an account as 'colourful' (pg. 254) or 'patently unconvincing' (pg. 253), one must imagine, not just that there is a reality 'out there' waiting for representation, but also that the facts of that reality, once spoken, can be somehow recognised as such. Nowhere is this assumption more evident than in Gough's (2004) analysis of men’s homophobia, in which he makes a series of judgements about the appropriateness or adequacy of his own participants’ talk. For example, 
Gough sees an element of hysteria in the way that Trev talks about homosexuality (see Extract One above). The suggestion is that Trev's expression of disgust carries too much potency or passion to be accounted for at an entirely local level. Its impetus must have come from elsewhere (i.e. Trevor's psyche). Likewise, the work of psychic forces is read into 'Martin's' account (on pg. 254) of the demeanour and appearance of homosexuals, on the basis that it simply doesn't square with reality. However, one of the cornerstones of discourse analytical work is the assumption that, as an analyst, one cannot (or, at least, should not presume to) know a priori what counts as an appropriate or warranted utterance. The analyst has no 'God's eye view' of the world and its workings. Instead, 'reality' or 'the truth' is treated as a participants' concern. Once again, it is seen as both the subject and the outcome of discourse, rather than its backdrop.

As a consequence of these differences, what we get in most attempts to combine discourse theory and psychoanalysis together is, not so much a synthesis, as the running of the two theories side-by-side. In the work of Gough (2004), for example, we can see this in the way that his analyses keep switching between a representational and a functional or performative view 
of language. Such an oscillation is inevitable, it seems to me, insofar as the two approaches rest on incompatible (meta)theoretical foundations. Indeed, it is worth recalling that discourse theory has a line on psychoanalysis; it sees it as a discourse (Moscovici, 1961/76). Parker (1997) is no doubt right in identifying psychoanalysis as key resource for the construction of contemporary selves. However, this is not the same as claiming that things like ‘repression', ‘sublimation' and other 'ego-defences' are actual mental events. In order to do that, one either has to turn one's back on discourse theory altogether or, at least, turn a blind eye to its legacy.

\section{Keeping the Faith}

In suggesting that discourse theory and psychoanalysis are theoretically incommensurate, I am clearly arguing that a choice needs to be made - and unsurprisingly, perhaps, my decision would be to stick within the terms of discourse theory. In part this decision is prompted by the fact that I remain convinced by post-structuralist arguments about the nature of language (which thereby precludes any easy alignment with psychoanalysis), but it also arises from the belief that a discursive approach to the study of men and masculinity can answer its critics without having to look outside of itself. 
Probably one of the easiest of rebuttals to make is against the claim that, on a purely empirical basis, some other level of explanation is necessarily required to make full sense of particular stretches of data. For example, in Extract One above, when Trev comes out with his 'oh no (.) uugghh I just couldn't' and later with 'it's just disgustin (.) I can't stand it', as we have seen, Gough interprets these remarks as unwarranted by the surrounding discursive context. They are treated as somehow excessive or 'over the top'. However, one could argue that, from a DP perspective, Trev is exploiting precisely this kind of interpretation to powerful rhetorical effect. The construction of oneself as viscerally disturbed by the mere thought of kissing another man can be seen as exquisitely designed in terms of how it harnesses an essentialist discourse of the self. The fact that Trev portrays himself as being constitutionally predisposed to finding such acts disgusting, shouldn't be taken at face value. Instead, it should be seen as a formulation that makes a highly robust claim to a heterosexual identity. Indeed, when looked at in this way, one could very well argue that the pervasiveness of homophobia in men and boys' discourse reflects, not its deep psychic origins at all, but its premier status as a routine (ethno)method for constructing oneself as straight (c.f. Nayak and Kehily, 1996). 
As one might expect, the charge that discursive approaches to studying men and masculinity lack an account or theory of the 'interior' space of the human mind is a little more difficult to counter. However, what seems quite certain is that discursive psychologists would want to resist the idea that there is some kind of firm dividing line between the social and the psychic. For them, there is no real difference between what lies within and what lies without. Indeed, as suggested by the Marxist psychologist, Lev Vygotsky (1978), we can conceive of thought as talk or conversation turned inwards (see Wertsch, 1985, 1991). What this means, of course, is that to study the realm of public discourse is to study the workings of the mind - it is not a poor substitute for the real thing. This idea receives further support from the work of Michael Billig (1987; Billig et al, 1988), who has shown that, as a form of inner speech, thought preserves the dialogic character of social discourse. What this seems to imply is that the complex, dynamic and inconsistent nature of subjectivity is a form of polyvocality or heteroglossia (see Bakhtin, 1981), rather than the product of an unconscious. In other words, the mind can be seen as the meeting place of many different voices all of social origins. Moreover, as Billig (1987) points out, these voices are related to one another rhetorically. To speak/ think in one voice is always, 
in some sense, to speak against or instead of another. What this, in turn, suggests is that a process such as repression can be understood in discursive, as opposed to psycho-dynamic terms (see Billig, 1997; 1998; 1999). It becomes simply that which remains unspoken or implicit rather than that which is banished from consciousness (c.f. Derrida, 1973).

A final point here is that, according to Billig et al (1988), it is the contradictory, or dilemmatic, character of culture that provides, both the impetus and resources, for all kinds of social/ subjective activity. In other words, we do not need another realm (such as the unconscious) in order to account for why men say and act the way that they do - there is sufficient ‘creative tension’ within culture itself.

It is not haphazard that common sense contains its contrary themes [...] that it possesses its dilemmatic character. The very existence of these opposing images, words, evaluations, maxims and so on is crucial, in that they permit the possibility not just of social dilemmas but of social thinking itself.

(Billig et al, 1988, pg. 17)

What this still leaves, of course, is the other major criticism of discourse approaches to studying men and masculinity mentioned at the start, which relates to the 'stickiness' of identity or the sense of 'bounded' subjectivity. As Freeman (1993) noted, in everyday life it does feel as though there is at 
least something about us that resists reconstruction; something that we carry with us from one social or discursive context to the next. As we have seen, for the psychoanalytically inclined, this 'something' is the characteristic furniture of the human psyche; that distinctive pattern or interplay of anxieties and ego-defences that compel us to be who we are. For the discursive psychologist, however, this obviously will not do.

Nevertheless, a thorough-going discursive explanation of the above must begin, I would argue, with the common sense notion that we are someone in particular. For what this demonstrates is that, in the West at least, there is a normative expectation that people will have their own mind and biography. We expect ourselves and others to be (reasonably) consistent in one's thoughts and actions - and, indeed, any dramatic deviation from those patterns is something for which a person is very likely to be held accountable. What this implies, of course, is that there doesn't have to be some kind of 'inner' or psychodynamic structure that anchors men to particular ways of being in the world. Rather, it means that, in our culture, producing oneself as consistent is a central discourse practice. As Foucault (1972) would say, the ideology of the Cartesian subject works to construct the object of which it speaks (see Edley, 2002). 
In conclusion, we should see that whilst DP can and does highlight the flexible deployment of language resources in the local production of masculinities, it can also account for patterns of consistency. It can account for the existence of recognizably individual selves as socially constructed realities. Men, I would argue, are highly accomplished (as) individuals. We all lie at the heart of a complex set of language-games that is the process of self-production.

\section{Notes:}

1. Although there is an obvious paradox here - for whilst DP has been criticised for exaggerating the extent of human agency, other poststructuralist theorists have been 'hauled over the coals' for implying exactly the opposite. For example, Laclau \& Mouffe (1985) have been criticised for suggesting that discourse is the principal or primary agent and that 'we' simply follow in its wake.

2. Whilst Tyson was both world famous and a multi-millionaire, his aggressive behaviour outside of the ring led to the failure of his marriage and then, later on, a prison sentence having been charged and found guilty of rape.

3. Interestingly, in a 2002 edition of the New Statesman, the British gay activist, Peter Tatchell, speculates as to whether or not Tyson himself was a repressed homosexual. 


\section{References}

Antaki, C. and S. Widdicombe (eds) (1998) Identities in Talk. London: Sage.

Atkinson, J.M. and J.C. Heritage (eds) (1984) Structures of Social Action: Studies in Conversation Analysis. Cambridge: Cambridge University Press.

Bakhtin, M. (1981) The Dialogic Imagination: Four Essays Austin: University of Texas Press.

Berger, P. and T. Luckmann (1985) The Social Construction of Reality: A treatise in the Sociology of Knowledge. Harmondsworth: Pelican.

Berger, M., B. Wallis and S. Watson (eds) (1995) Constructing Masculinity. London: Routledge.

Billig, M. (1987) Arguing and Thinking. Cambridge: Cambridge University Press.

Billig, M. (1997) 'The Dialogic Unconscious: Psychoanalysis, discursive psychology and the nature of repression'. British Journal of Social Psychology. Vol. 36(2): 139-159.

Billig, M. (1998) 'Dialogic Repression and the Oedipus Complex: Reinterpreting the Little Hans Case'. Culture and Psychology. Vol. 4(1): 11-47.

Billig, M. (1999) Freudian Repression: Conversation Creating the Unconscious. Cambridge: Cambridge University Press.

Billig, M., S. Condor, D. Edwards, M. Gane, D. Middleton and A. Radley (1988) Ideological Dilemmas: A Social Psychology of Everyday Thinking. London: Sage.

Bowers, J. (1988) Review of Potter \& Wetherell's Discourse and Social Psychology. British Journal of Social Psychology, Vol. 27, 185-192. 
Carrigan, T, Connell, R. and Lee, J. (1985) Towards a new sociology of masculinity. Theory and Society, 14, 551-604.

Chodorow, N. (1989) Feminism and Psychoanalytic Theory. New Haven: Yale University Press.

Crossley, M.L. (2000) 'Narrative Psychology, Trauma and the Study of Self/Identity’. Theory \& Psychology, Vol. 10(4): 527-46.

Davies, B. and R. Harré (1990) Positioning: The Discursive Production of Selves. Journal for the Theory of Social Behaviour, Vol. 20, 43-65.

Derrida, J. (1973) Speech and Penomena and Other Essays on Husserl's Theory of Signs. Evanston: Northwestern University Press.

Edley, N. (2001) 'Analysing Masculinity: Interpretative repertoires, subject positions and ideological dilemmas' in Wetherell, M., Taylor, S. and Yates, S.J. (eds) (2001) Discourse as Data: A Guide to Analysis. London: Sage and the Open University.

Edley, N. (2002) 'The Loner, the Walk and the Beast Within: Narrative Fragments in the Construction of Masculinity' in W. Patterson (ed.) Strategic Narrative: New perspectives on personal and cultural narratives. Lexington Books.

Edley, N. and M. Wetherell (1997) Jockeying for Position: the construction of masculine identities Discourse and Society 8 (2): 203-17.

Edley, N. and M. Wetherell (1999) Imagined Futures: Young men's talk about fatherhood and domestic life. British Journal of Social Psychology Vol. 38, 181-194.

Edwards, D. (1997) Discourse and Cognition. London: Sage.

Edwards, D. and J. Potter (1992) Discursive Psychology. London: Sage.

Foucault, M. (1972) The Archaeology of Knowledge. London: Tavistock.

Freeman, M. (1993) Rewriting the Self: History, memory, narrative. London: Routledge. 
Frosh, S. (1993) 'The seeds of male sexuality'. In J. Ussher and C. Baker (eds.) Psychological Perspectives on Sexual Problems. London: Routledge.

Frosh S. (1999) 'What is outside discourse?' Psychoanalytic Studies. Vol. 1: 381-91.

Frosh, S. (2000) 'Intimacy, Gender and Abuse: The Construction of Masculinities' in U. McCluskey and C. Hooper (eds) Psychodynamic Perspectives on Abuse: The Cost of Fear. London: Jessica Kingsley.

Frosh, S., A. Phoenix and R. Pattman (2000) 'But it's racism I really hate': Young masculinities, racism and psychoanalysis'. Psychoanalytic Psychology Vol. 17: 225-242.

Frosh, S., A. Phoenix and R. Pattman (2002) Young Masculinities: Understanding Boys in Contemporary Society. London: Palgrave.

Frosh, S., A. Phoenix and R. Pattman (2003) 'Taking a Stand: Using psychoanalysis to explore the positioning of subjects in discourse'. British Journal of Social Psychology Vol. 42(1): 39-53.

Garfinkel, H. (1967) Studies in Ethnomethodology. Englewood Cliffs, New Jersey: Prentice-Hall.

Gough, B. (1998) 'Men and the discursive reproduction of sexism: Repertoires of difference and equality’. Feminism \& Psychology. Vol. 8: 25-49.

Gough, B. (2004) 'Psychoanalysis as a resource for understanding emotional ruptures in the text: The case of defensive masculinities' British Journal of Social Psychology. Vol. 43 (2): 245-67.

Greenson, R. (1968) 'Dis-identifying from mother: Its special importance for the boy'. International Psychoanalytic Journal, 49, 370-4.

Hollway, W. and T. Jefferson (2000) Doing Qualitative Research Differently: Free association, narrative and the interview method. London: Sage. 
Jefferson, T. (1996) 'From "little fairy boy" to the "compleat destroyer": subjectivity and transformation in the biography of Mike Tyson' in M. Mac An Ghaill (ed.) Understanding Masculinities: Social Relations and Cultural Arenas Buckingham: Open University Press.

Jefferson, T. (1997) 'The Tyson rape trial: the law, feminism and emotional "truth”'. Social and Legal Studies, Vol. 6(2): 281-301.

Jefferson, T. (1998) ‘Muscle, “hard men”, and “iron” Mike Tyson: reflections on desire, anxiety and the embodiment of masculinity'. Body and Society Vol. 4(1): 77-98.

Johnson, S. and U.H. Meinhof (eds) (1997) Language and Masculinity. Oxford: Blackwell.

Kessler, S. and W. McKenna (1978) Gender: An Ethnomethodological Approach. New York: Wiley.

Klein, M. (1988a) Love, Guilt and Reparation and Other Works, 1921-1945. London: Virago.

Klein, M. (1988b) Envy and Gratitude and Other Works, 1946-1963. London: Virago.

Laclau, E. and C. Mouffe (1985) Hegemony and Socialist Strategy: Towards a Radical, Democratic Politics. London: Verso.

Moscovici, S. (1961) La Psychoanalyse, son Image et son Public (Second Edition, 1976). London: Academic Press.

Nayak, A. and M. Kehily (1996) 'Playing it straight: Masculinities, homophobias and schooling’. Journal of Gender Studies, Vol. 5: 211230.

Parker, I. (1997) 'Discourse analysis and psychoanalysis'. British Journal of Social Psychology. Vol. 36: 479-495.

Redman, P. (2000) 'Tarred with the Same Brush': 'Homophobia' and the Role of the Unconscious in School-based Cultures of Masculinity. Sexualities, Vol. 3(4): 483-499. 
Seidler, V.J. (1989) Rediscovering Masculinity: Reason, Language and Sexuality. New York: Routledge.

Tatchell, P. (2002) 'What's eating Mike Tyson?' New Statesman, $10^{\text {th }}$ June: $15-16$.

Vygotsky, L.S. (1978) Mind in Society: The development of higher psychological processes. Cambridge, MA.: Harvard University Press.

Wertsch, J. (1985) Vygotsky and the Social Formation of Mind. Cambridge, M.A.: Harvard University Press.

Wertsch, J. (1991) Voices of the Mind: A Sociocultural approach to Mediated Action. Hemel Hempstead: Harvester Wheatsheaf.

West, C. and D.H. Zimmerman (1991) 'Doing Gender' in J. Lorber and S.A. Farrell (eds) The Social Construction of Gender Newbury Park: Sage.

Wetherell. M and Edley, N. (1999) 'Negotiating Hegemonic Masculinity: Imaginary Positions and Psycho-Discursive Practices'. Feminism and Psychology, Vol. 9 (3) 335-356.

Willott, S. and Griffin, C. (1997) “"Wham Bam, Am I a Man?” Unemployed Men Talk about Masculinities', Feminism and Psychology, Vol. 7(1) 107-28. 